\title{
PENGARUH TERAPI REMINISCENCE TERHADAP FUNGSI KOGNITIF LANSIA DI UPT PSTW BONDOWOSO
}

\author{
Sofia Rhosma Dewi \\ Fakultas Ilmu Kesehatan Universitas Muhammadiyah Jember \\ 8e-mail: sofiarhosma84@gmail.com
}

\begin{abstract}
ABSTRAK
Pada masa tua banyak sekali masalah yang terjadi, salah satunya adalah fungsi kognitif. Penurunan fungsi kognitif pada lansia belum mendapatkan penanganan yang maksimal. Salah satu bentuk terapi untuk fungsi kognitif lansia adalah terapi Reminiscience. Penelitian ini bertujuan untuk mengidentifikasi pengaruh terapi Reminiscience terhadap peningkatan fungsi kognitif lansia di UPT PSTW Bondowoso Penelitian ini adalah penelitian pra eksperimental dengan pendekatan pre - post test design. Populasi dalam penelitian ini adalah 81 lansia yang tinggal di UPT PSTW Bondowoso. Responden yang terlibat dalam penelitian ini adalah 20 lansia yang diambil dengan purposive sampling dengan kriteria inklusi lansia yang kooperatif, mudah diajak berkomunikasi dan bersedia menjadi responden.. Penelitian dilakukan selama bulan Maret 2018. Responden terbagi dalam 4 kelompok. Setiap kelompok melakukan terapi Reminiscience selama 90 menit setiap sesi dan dalam dua minggu dilakukan tiga sesi untuk masing- masing kelompok. Fungsi kognitif lansia diukur dengan menggunakan MMSE sebelum dan sesudah tindakan. Analisa data dilakukan dengan menggunakan uji wilcoxon. Hasil uji wilcoxon menunjukkan $p$ value 0.09 lebih kecil dari $\alpha$ 0.05 sehingga $\mathrm{H} 0$ ditolak artinya ada pengaruh terapi Reminiscience terhadap peningkatan fungsi kognitif lansia. Terapi ini direkomendasikan sebagai salah satu terapi yang dapat dilakukan dalam upaya mempertahankan fungsi kognitif lansia

Kata kunci : lansia, fungsi kognitif, terapi reminiscience
\end{abstract}

\section{ABSTRACT}

There are so many problem that happen in older age, one of them is decreasing of cognitive function. This problem hasn't get maximum intervention. One of therapy that can be done to maintain elderly's cognitive function are reminiscience theraphy. This study is conduct to find out the effectiveness of reminiscience therapy to maintain elderlys cognitive function in Bondowoso state nursing home. It's a pre experimental study with pre and post test approach. The population are 81 elderly living in Bondowoso state nursing home. The respondents who taking a part in this study are 20 elderly taken by purposive sampling including elderly who are cooperative, easy to communicate with and agree to taking a part as respondent. This study is conduct in March 2018. The respondents are divided into 4 groups. Each group is doing reminiscience therapy for 90 minutes at each session and three sessions were done within two weeks. Elderlys cognitive function was measured by using MMSE before and after the therapy. Data analysis using wilcoxon signed test show p value 0.09 mean reminiscience therapy is effective in maintainig elderly's cognitive function. Since it effectiveness, this therapy is recommended to be done in order to maintain elderly's cognitive function.

Keywords : elderly, cognitive function, therapy reminiscience

\section{PENDAHULUAN}

Proses menua merupakan proses fisiologis yang dihadapi oleh setiap orang.
Usia permulaan tua menurut UU nomor 13 tahun 1998 tentang lanjut usia menyebutkan bahwa umur 60 tahun adalah 
usia (Nugroho, 2008). Pada masa tua banyak sekali masalah yang terjadi, salah satunya adalah fungsi kognitif. Penurunan fungsi kognitif ini biasanya ditandai dengan adanya gangguan mengingat dan mempelajari suatu hal yang baru, gangguan kelancaran bicara, keliru mengenali tempat dan waktu, orang atau benda, sulit menghitung, tidak mampu lagi membuat rencana, tidak dapat mengatur kegiatan, tidak dapat mengambil keputusan, penurunan kosentrasi dan tingkat kewaspadaan. Penurunan fungsi kognitif pada lansia dapat menyebabkan beberapa penyakit berbahaya yang dapat membahayakan lansia, misalnya demensia. Lansia yang mengalami demensia sangat beresiko mengalami jatuh, bahkan terjadi kecelakaan apabila kurang pengawasan dari keluarga (Sumijatun, 2005).

Meningkatnya populasi lansia akan dapat menimbulkan masalah - masalah penyakit usia lanjut pada lansia. Jumlah penduduk lansia di Indonesia pada tahun 2006 sebesar \pm 19 juta $(8,9 \%)$, pada tahun 2010 sebesar 23,9 juta $(9,77 \%)$, sedaangkan pada tahun 2020 diperkirakan sebesar 28,8 juta $(11,34 \%)$ (Badan Pusat Statistik, 2010). Menurut data Departemen Kesehatan tahun 1998, di Jawa Timur terdapat $7,2 \%$ populasi lansia untuk kasus demensia. Sebanyak 5\%lansia usia $60-74$ tahun mengalami penurunan fungsi kognitif dan menderita penyakit demensia dan diperkirakan akan meningkat dua kali lipat setiap 5 tahunnya mencapai lebih dari $45 \%$ pada usia di atas 85 tahun (Nugroho, 2008).

Fenomena peningkatan proporsi populasi lansia juga terjadi di kota Bondowoso. Setiap tahun terjadi peningkatan jumlah lansia di UPT PSTW Bondowoso sebesar $4-7 \%$. Hal ini sedikit banyak juga berkontribusi terhadao terjadinya berbagai macam masalah lansia seperti kemunduran fisik, mental, sosial, produktifitas kerja, komunikasi dan terbatasnya aksesibilitas di Indonesia. Salah satu masalah yang timbul akibat proses menua adalah timbulnya gangguan kognitif.

Gangguan kognitif dapat dicegah dengan memperbanyak aktifitas gerak dan pemikiran yang melibatkan otak bagian kanan dan kiri (Khuluq, 2009). Fenomena yang terjadi di lapangan menunjukkan bahwa penurunan fungsi kognitif pada lansia belum mendapatkan penanganan yang maksimal. Teknik yang selama ini digunakan memiliki kelemahan tersendiri sehingga tujuan peningkatan fungsi kognitif belum maksimal untuk dicapai. Teknik peningkatan fungsi kognitif lanisa harus dibuat lebih mudah dan efektif. Salah satunya adalah terapi Reminiscience. Reminiscience merupakan salah satu metode pengekspresian perasaan yang akan memicu munculnya rasa percaya diri dan perasaan dihargai pada lansia yang berdampak pada munculnya koping positif yang mempengaruhi persepsi dan emosi lansia dalam memandang suatu masalah. Terapi ini bertujuan untuk membantu meningkatkan fungsi kognitif pada lansia (Jahanbin, 2013).

Terapi Reminiscience masih jarang diminati di Indonesia akibat kurang maksimalnya sosialisasi kepada masyarakat sehingga penurunan fungsi kognitif pada lansia masih menjadi masalah utama. Penelitian ini bertujuan untuk mengidentifikasi pengaruh terapi Reminiscience terhadap peningkatan fungsi kognitif lansia di UPT PSTW Bondowoso.

\section{METODE}

Penelitian ini adalah penelitian pra eksperimental dengan pendekatan pre post test design. Populasi dalam penelitian ini adalah 81 lansia yang tinggal di UPT PSTW Bondowoso. Responden yang terlibat dalam penelitian ini adalah 20 lansia yang diambil dengan purposive sampling dengan kriteria inklusi lansia yang kooperatif, mudah diajak berkomunikasi dan bersedia menjadi responden.. Penelitian dilakukan selama bulan Maret 2018. Responden terbagi 
dalam 4 kelompok. Setiap kelompok dilakukan terapi Reminiscience selama 90 menit setiap sesi dan dalam dua minggu dilakukan tiga sesi untuk masing- masing kelompok. Fungsi kognitif lansia diukur dengan menggunakan MMSE sebelum dan sesudah tindakan. Analisa data dilakukan dengan menggunakan uji wilcoxon.

\section{HASIL}

Tabel 1. Karakteristik Responden Penelitian

\begin{tabular}{cll}
\hline Karakteristik & \multicolumn{1}{c}{$\mathrm{n}$} & \multicolumn{1}{c}{$\%$} \\
\hline Usia & & \\
$60-69$ & 4 & 20 \\
$70-79$ & 10 & 50 \\
$80-89$ & 6 & 30 \\
Tingkat Pendidikan & & \\
Tidak sekolah & 2 & 10 \\
SD & 6 & 30 \\
SMP & 8 & 40 \\
SMA & 4 & 20 \\
Jenis Kelamin & & \\
Laki - laki & 12 & 60 \\
Perempuan & 8 & 40 \\
\hline Jumlah & 20 & 100 \\
\hline
\end{tabular}

Berdasarkan data pada tabel 1 dapat dilihat bahwa mayoritas responden dalam penelitian ini berusia 70 - 79 tahun, mengenyam pendidikan SMP, dan berjenis kelamin laki - laki.

Tabel 2. Fungsi Kognitif Lansia Sebelum dan Sesudah Terapi Reminiscience

\begin{tabular}{lccc}
\hline & $\begin{array}{c}\text { Pre } \\
\text { test }\end{array}$ & $\begin{array}{c}\text { Post } \\
\text { test }\end{array}$ & \\
\cline { 1 - 3 } Jumlah & 20 & 20 & P \\
Mean & 12.80 & 14.10 & value \\
St. deviasi & 1.751 & 2.234 & 0,009 \\
Minimum & 10 & 10 & \\
Maximum & 15 & 17 & \\
\hline
\end{tabular}

Hasil analisis sebelum dan sesudah dilakukan terapi Reminiscience menunjukkan bahwa status kognitif lansia berada pada rerata 12.80 dengan nilai minimum 10 dan nilai maksimum adalah
15. Sedangkan setelah dilakukan terapi Reminisciece rerata status kognitif lansia adalah 14.10 dengan nilai minimum 10 dan nilai maksimum 17. Hasil uji wilcoxon menunjukkan $\mathrm{p}$ value 0.09 lebih kecil dari $\alpha 0.05$ sehingga $\mathrm{H} 0$ ditolak artinya ada pengaruh terapi Reminiscience terhadap peningkatan fungsi kognitif lansia.

\section{PEMBAHASAN}

Hasil analisis sebelum dilakukan terapi Reminiscience menunjukkan status kognitif lansia berada pada rerata 12.80 dengan nilai minimum 10 dan nilai maksimum adalah 15. Berdasarkan karakteristik responden terlihat bahwa responden pada penelitian ini mayoritas berusia lebih dari 70 tahun. Usia merupakan faktor yang mempengaruhi perubahan fungsi kognitif lansia. Hal ini sesuai dengan pendapat Shciae (2003) yang menyebutkan ada perubahan yang terjadi di otak akibat pertambahan usia, diantaranya adalah perubahan pada fungsi penyimpanan informasi (storage). Jenis kelamin juga berpenagruh terhadap fungsi kognitif. Responden pada penelitian ini mayoritas laki - laki. Schiae (2003) menyebutkan laki - laki diduga lebih banyak dan cenderung untuk menjadi pelupa. Hal ini disebabkan oleh pengaruh stres yang mengakibatkan penurunan memori. Reseptor estrogen pada laki - laki ditemukan dalam area otak yang berperan dalam fungsi belajar dan memori seperti pada hipokampus. Rendahnya level estradiol dalam tubuh dikaitkan dengan penurunan fungsi kognitif umum dan memori verbal.

Proses menua dapat menurunkan kemampuan kognitif dan menyebabkan kepikunan. Masalah kesehatan kronis dan penurunan fungsi kognitif serta memori. Gejala penurunan kognitif ringan berupa melambatnya proses pikir, kurang menggunakan strategi memori yang tepat, kesulitan memusatkan perhatian, mudah terdistraksi pada hal yang kurang perlu dan memerlukan waktu yang lebih lama untuk berlajar. 
Terapi reminiscience akan memicu impuls pada memori. Memori adalah proses penyimpanan impuls sensorik penting untuk dipakai pada masa yang akan datang sebagai pengatur aktifitas motorik dan pengolahan berpikir. Sebagian besar penyimpanan ini terjadi dalam korteks serebri. Korteks yang mempunyai sel otak lebih dari 10 milyar sel terhubung dengan sel - sel lain di daerah otak. Tiap sel otak mempunyai hubungan dengan 4 ribu hingga 10 ribu sel otak lainnya dan berhubungan melalui impuls listrik dan zat kimia yang disebut neurotransmitter.

Proses penyimpanan informasi juga merupakan fungsi dari sinaps. Setiap sinyal sensorik tertentu yang melewati serentetan sinaps di masa datang akan mampu ,emjalarkan sinyal yang sama. Bila sinaps tersebut sudah seringkali dilewati oleh sinyal sensorik maka sinyal itu akan akan begitu terfasilitasi sehingga sinyal yang timbul dari otak sendiri saja sudah dapat menjalankan impuls melalui serentetan sinaps yang sama walaupun belum timbul masukan sensoris.

Proses pemikiran bawah sadar bermula dari kegiatan fasilitas sinaps ini. Hal ini akan menimbulkan suatu persepsi dari pengalaman sensasi yang sebenarnya dan mendapat respon tubuh walaupun pengaruh ataupun akibat yang timbul hanyalah suatu memori dari suatu sensasi. Sekali memori tersimpan dalam sistem saraf maka memori tersebut akan menjadi bagian mekanisme pengolahannya.

Terapi Reminiscience memberikan kesempatan kepada anggota kelompok untuk membangun hubungan baru dalam kelompok yang berdampak positif dan berlangsung dalam suasana santai. Melalui terapi Reminiscience setiap anggota akan melibatkan diri dalam diskusi menyenangkan tentang masa lalu sehingga memberikan efek relaksasi dan menimbulkan hubungan yang harmonis.

\section{KESIMPULAN}

Terapi Reminiscience terbukti berpengaruh terhadap peningkatan fungsi kognitif lansia.

\section{SARAN}

Sehingga diharapkan terapi ini dapat dijadikan sebagai salah satu terapi yang dapat dilakukan dalam kegiatan pembinaan lansia di UPT PSTW Bondowoso.

\section{KEPUSTAKAAN}

Boekhorst, S., M, D., A, F. \& Twisk, S., 2013. Quality of LIfe of Nursing Home Residents with Dementia Subject to Surveillance Technology Versus Physical Restraints : An Explorative Study. International Journal of Geriatric Psychiatry, 28(4), pp. 356 - 363.

Kesehatan, P. D. d. I. K., 2013. Buletin dan Jendela Informasi Kesehatan. Gambaran Kesehatan Lanjut Usia di Indonesia, 12 Juli, pp. 1-17

Lachman, V. D., 2012. Applying the Ethics of Care to Your Nursing Practice. Medical Surgical Nursing, 21(2), pp. 112 - 116.

Malone, L. K., Fletcher, R. K. \& Plank, L. M., 2004. Management Guideline for Nurse Practicioners Working With Older Adult. 2nd Edition penyunt. Philadelphia: F A Davis Company.

Mauk, K. L., 2012. Gerontolical Nursing Competencies for Care. 4th Edition penyunt. Boston: Jones and Bartlett Publisher.

Nursalam, 2013. Metodologi Penelitian Ilmu Keperawatan. Jakarta: Salemba Medika.

Park, D. C., Gutchess, A. H., Meade, M. \& Stine-Morrow, E. L., 2007. Improving Cognitive Function in Older Adults : Nontraditional Approaches. Journal of Gerontology, 62B(I), pp. 45 - 52.

Perry \& Potter, 2005. Buku Ajar Fundamental Keperawatan : 
Konsep, Proses dan Praktik. 3 penyunt. Jakarta: EGC

Schiae, W. K., 2003. Cognitive Aging, Washington DC: National Research Council. 